Images in...

\title{
Distal pacemaker lead fracture: a rare entity
}

\author{
D X Augustine, ${ }^{1} \mathrm{~K}$ Carson, ${ }^{1} \mathrm{~A}$ Garg ${ }^{2}$ \\ ${ }^{1}$ Department of Cardiology, RUH Bath NHS Foundation Trust, Bath, UK \\ ${ }^{2}$ RUH Bath NHS Foundation Trust, Bath, UK
}

Correspondence to DX Augustine, dxaugustine@hotmail.com

\section{DESCRIPTION}

An 87-year-old woman from a nursing home with a history of ventricular rate responsive demand (VVIR) Microny II SR (St. Jude Medical AB, Järfälla, Sweden) pacemaker insertion for syncope with complete heart block in 2003 was admitted following an episode of loss of consciousness. This occurred as she was being helped to the toilet by two carers each supporting her under one arm.

On admission her pulse was 40 beats/min. Her admission electrocardiogram (ECG) (figure 1) demonstrated intermittent ventricular pacing spikes failing to capture with an underlying rhythm of complete heart block and a ventricular rate of 40 beats/min. Her chest radiograph (figure 2, left panel) showed a distal ventricular pacing lead fracture. Pacemaker interrogation revealed a ventricular lead failing to sense or pace with high impedance. A pacemaker check 8 months previously was satisfactory.
She underwent an uneventful new ventricular lead insertion and was discharged. The distal lead fracture (St Jude 1470T lead) was more evident during screening (figure 2, right). We were informed by St Jude Medical that this type of lead fracture is the first reported case documented with them worldwide. The patient died several months following discharge.

The incidence of pacemaker lead fracture has been reported to be as high as $7.2 \%,{ }^{1}$ almost all of which occur in the infraclavicular region as a result of compression between the clavicle and first rib. To our knowledge this is the first reported case of this type of distal ventricular lead fracture. We can only postulate as to the mechanism of this incident. It was reported that over the preceding few months the patient had required increasing support while walking, and it may be this contributed to the lead fracture.

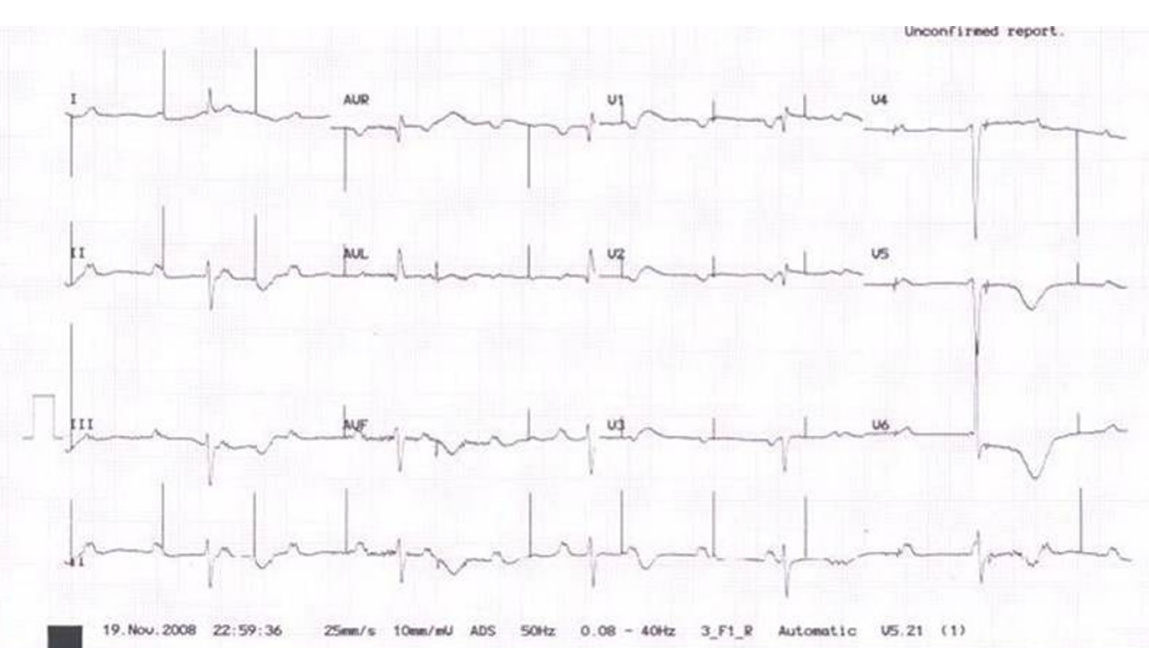

Figure 1 Electrocardiogram on admission. 


\section{BMJ Case Reports}

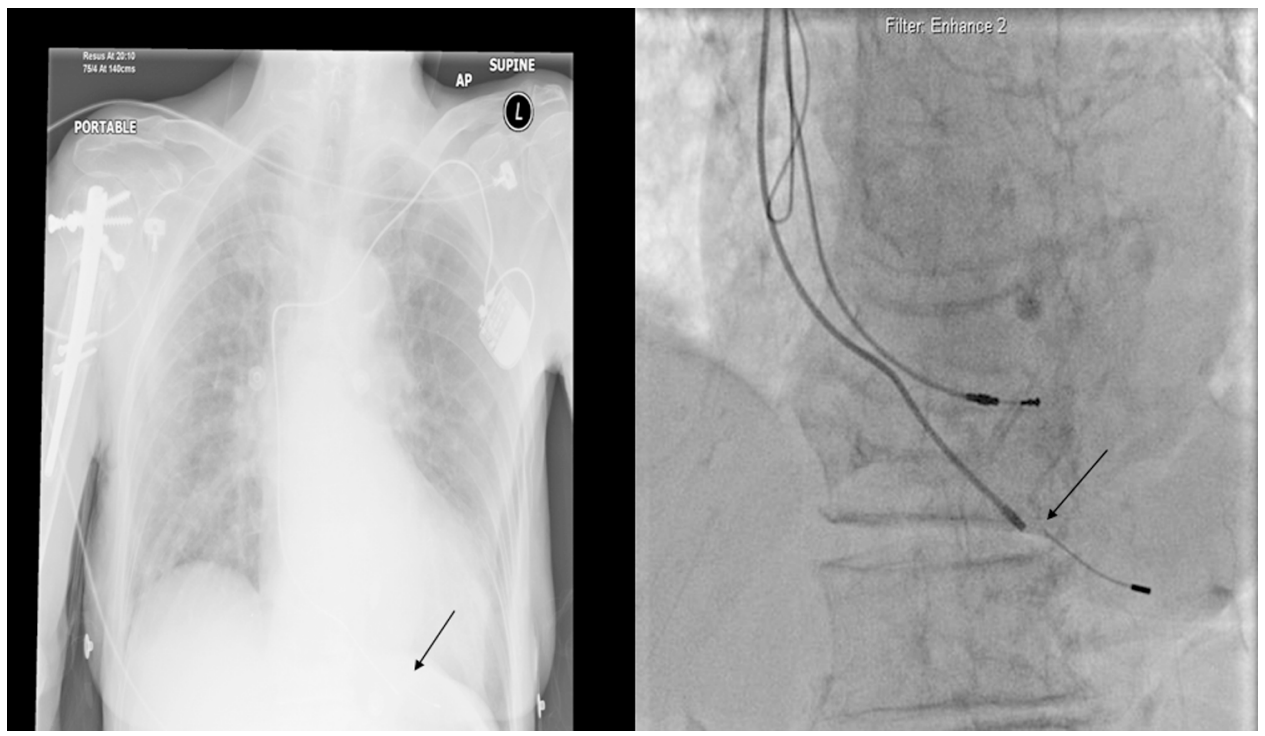

Figure 2 Left: chest radiograph showing distal lead fracture (arrow); right: acquisition at time of pacing showing distal lead fracture (arrow).

\section{REFERENCES}

Competing interests None

Patient consent Not Obtained.
Olgun H, Karagoz T, Celiker A, et al. Patient- and lead-related factors affecting lead fracture in children with transvenous permanent pacemaker Europace 2008:10:844-7.

This pdf has been created automatically from the final edited text and images.

Copyright 2010 BMJ Publishing Group. All rights reserved. For permission to reuse any of this content visit

http://group.bmi.com/group/rights-licensing/permissions.

BMJ Case Report Fellows may re-use this article for personal use and teaching without any further permission.

Please cite this article as follows (you will need to access the article online to obtain the date of publication).

Augustine DX, Carson K, Garg A. Distal pacemaker lead fracture: a rare entity. BMJ Case Reports 2010;10.1136/bcr.05.2010.3019, date of publication

Become a Fellow of BMJ Case Reports today and you can:

Submit as many cases as you like

- Enjoy fast sympathetic peer review and rapid publication of accepted articles

- Access all the published articles

- Re-use any of the published material for personal use and teaching without further permission

For information on Institutional Fellowships contact consortiasales@bmjgroup.com

Visit casereports.bmj.com for more articles like this and to become a Fellow 